\title{
EMPOWERING “THE OTHER”
}

\author{
Lawrence D. Bobo \\ Department of African and African American Studies and Department of Sociology, \\ Harvard University
}

It is never easy to be a member of a "marked" category. To be mainstream, to enjoy membership in the dominant class, the privileged group why, that seems hardly a designation at all and certainly not a constraint or imposition. The burden, bite, and sting of categorical distinction is something borne by "the other." It is those who are not full members, not one "of us," those who are lesser and most of all among "the others" who understand and feel the depth of stigmatization, of inequality, of social constraint.

Such "othering" is a multilayered and complex phenomenon. It entails not merely the circumstance and lived experience of disadvantage in economic, political, and social esteem, but a profoundly compromised vocabulary, analytical, and normative framework for contesting such degradation. The Du Bois Review: Social Science Research on Race has always been committed to facilitating the development and deployment of those new vocabularies, re-fashioned analytical approaches, and contested normative frameworks. This is how we empower "the other."

For far too long, research on families of color was seen by social scientists through a particular normative lens. From this vantage point, Black families in particular were deviant, lesser; other; lacking the proper structure, role differentiation, functions, and guiding culture. Children hailing from such damaged foundations, and worse yet, communities chock-full of households, were ripe for dysfunction and failure. It is a well-known script.

At least two generations of scholars have tried to repair the damage done to our "knowledge base" about Black families by the imposition of, and mechanical measurement against, a post-World War II, middle class, White, patriarchical, heterosexual model of proper familial social organization. Hence, the idea of bringing a cultural lens to new studies of Black male roles might be regarded with some skepticism. Yet, Maria S. Johnson and Alford A. Young, Jr. make a strong case regarding the necessity for such work. They also formulate a more viable analytical posture from which to launch such research. Johnson and Young stress that the actual roles, orientations, and behaviors of Black fathers have been sorely under-researched and, when the focus of research, are all too often seen only through stereotyped and stigmatizing lenses. These authors propose taking a far more inductive approach to culture, family roles, and fatherhood. This approach would center on how Black fathers understand and construct their roles, what parenthood and parental obligation means to them, how it

Du Bois Review, 13:1 (2016) 1-4.

(C) 2016 Hutchins Center for African and African American Research 1742-058X/16 \$15.00

doi:10.1017/S1742058X16000096 
gets negotiated, and what challenges and constraints, as well as resources and opportunities, they face as they seek to fulfill the role of fatherhood as they live and understand it. Such an approach would free scholarship, Johnson and Young suggest, from the distorting gaze and yardstick of White middle class normativity that has so bedeviled earlier scholarship in this area.

If White middle class normativity is under challenge in scholarship on the family, it is very much on the rise with regard to the legal and political status of voting rights in the United States. The 2013 U.S. Supreme Court ruling in Shelby v. Holder invalidated section 4(b) of the Voting Rights Act of 1965, the "pre-clearance" rule that has been the bulwark of protecting minority voting rights in states with prior track records of clear racial discrimination. Almost instantly following this ruling, as political scientists Desmond King and Rogers M. Smith recount, Republican governors and state legislators began introducing legislation imposing new rules on voting eligibility, rules that would almost without exception disproportionately hamper access to the ballot for minority voters. In a historically well-grounded and provocative argument, King and Smith call for us to understand this wave of post-Shelby voting hindrances in the context of their theory of competing racial political orders. On one side of this competition stand a set of organizations and actors putatively seeking a completely "colorblind" political order, but who do so in order to preserve or enhance entrenched White privilege. On the other side of this competition are a set of organizations and actors who seek "race conscious" political order in order to systematically fight discrimination and continue the work of dismantling White privilege. The competing racial orders model provides considerable analytical leverage on the current political dynamics of race in the United States.

In one sense the emergence of the "Rhodes Must Fall" movement in South Africa and the United Kingdom exemplify the next stage of empowering those who had been the other. In particular, the reign of middle class White normativity in the newly democratic South Africa now faces an acute test. For many, the rush to see a post-apartheid South Africa as now a mainly economically stratified and increasingly postracial social order is increasingly seen as simply too rapid an elision of deeply structured racial inequalities. In this vein, Xolela Mangcu calls for a serious scholarly project of de-colonizing sociological scholarship and thinking in South Africa. In this enormously provocative argument he draws upon Henry Louis Gates, Jr.'s notion of a "shared text of Blackness." In so doing, he forges a link between the likes of Frederick Douglass and W. E. B. Du Bois, Robert Sobukwe and Steven Biko. His analysis should spark an important discussion and a needed corrective effort for a fresh view of inequality in South Africa (and other nation states re-negotiating their respective racial divides). At the core of this effort must be, as Mangcu suggests, writing the contributions of Black African scholars and thinkers into the sociological fabric for thinking about the organization of social life in South Africa.

"Othering" is not a static and fixed social outcome. It is a process involving steady contestation from those "othered" and constant adaptation and efforts to retain hegemony on the part of those in a position to impose "othering." Law, policing, and the criminal justice system often constitute the front line in systems of group inequality. In this regard Robert J. Durán examines the disposition and media treatment over thirty years of officer involved shootings in the city and county of Denver, Colorado. Sadly, the bottom line is a story we now know all too well. First, Latino youth and especially African American youth are heavily overrepresented among those shot or killed by police; and, second, police officers are almost never held criminally liable for shooting deaths, even when the victims are unarmed and other aspects of the case point strongly in the direction of police corruption and abuse. One senses in these patterns 
not merely a desire for "law and order" or respect for the difficult job of policing, but something far more deep, fundamental, and one would hope disquieting about the prevailing terms and boundary lines of real membership in a moral community.

Researchers have increasingly examined the impact of the growing "representation" of women and racial minorities in political decision-making bodies at the local, state, and federal level. The overwhelming fraction of this work has sought to determine if descriptive or demographic representation produces any real difference in the substance of politics and political decision-making. Accordingly, scholars seek to determine if women legislators vote differently or have a different agenda than male legislators. They ask, do minority legislators seek different outcomes than otherwise similar White legislators? Missing in much of this work has been a more genuinely intersectional analysis of how the conjunction of race and gender may affect policy orientations and outcomes. Political scientists Nadia E. Brown and Sarah Allen Gershon take an important step in filling this lacuna. They examine 187 official Congressional website biographies. The results show that the web biographies of minority women legislators more often expressly discuss the importance of their gender, race/ethnicity, and class background to their policy positions than do those of their male (minority or non-minority) and White female counterparts.

Three articles in this issue deal with how processes of immigration influence the understanding of race and race relations. One focuses on theoretical social comparison processes that serve to differentiate new immigrants from native African Americans in what is arguably an "othering" process. A second piece focuses on how anti-immigrant legislation appears to reduce a sense of difference separating native African Americans from immigrants. And a third piece focuses on how immigration-driven population changes complicate the social landscape as perceived and negotiated by increasingly displaced African Americans. Sociologist Mosi Adesina Ifatunji uses data from the 2004 National Survey of American Life to shed light on whether there is clear and consistent evidence that Afro-Caribbean Blacks are a model minority relative to native born African Americans. Both in terms of ratings on five domains of cultural orientation and of the impact of these measures on socioeconomic attainment, Ifatunji finds at best weak support for the model minority hypothesis. The hypothesis itself, he implies, can in fact be seen as part of a dominant "othering" discussion that pulls attention away from lines of social critique and political change that might more properly be the focus of scholarly attention.

Political scientist Kim M. Williams and sociologist Lonnie Hannon, III examine a circumstance where a profound act of political "othering" forged a stronger tie been African American leaders and immigrant communities. Using a case study approach they examine how the Black elite in Birmingham, Alabama view the issue of immigration in years prior to 2010 and then after the 2010 passage of House Bill 56, or the "Beason-Hammon Alabama Taxpayer and Citizen Protection Act," perhaps the most extreme anti-immigrant legislation enacted by any state government in recent years. Their results suggest that African American elites in the post-H.B. 56 period increasingly framed "immigrant rights" as a civil rights issue, a matter much closer to their own values and interests than it had been before.

Sociologist Tomás Jiménez focuses on a population shift in East Palo Alto, California, a community that has swung rapidly from 60\% African American in 1980 to less than 20\% African American in 2010, and from about 15\% Hispanic in 1980 to $65 \%$ Hispanic in 2010. His ethnographic observation and in-depth interviews with African Americans in this community suggest that they do not rely on a simple Black versus Hispanic binary in their thinking. Despite feeling a profound sense of change and displacement they see the Hispanic population as varying along important axes 
of English language fluency and tenure in the community, with the configuration of these attributes greatly influencing the potential for cooperation or conflict.

Is "othering" a personal, moral, and psychological failing or is it a social, systemic, and collective problem? Sociologists James Thomas and W. Carson Byrd aim to problematize the tendency to read acts of bias, discrimination, and inter-racial hostility as indicative of an individual ailment best treated with a therapeutic or counseling response. The problem is less one of personal sickness, they suggest, than it is of societal structures and deep cultural practices that call for supra-individual remedies.

What happens when "the other" claims power? Sociologist and American Studies scholar Michael P. Jeffries probes a richly nuanced and probing review of Michael Eric Dyson's recent major book on the Obama presidency. Jeffries embraces much of the Black left intellectual critique that has been directed at Obama over the years, but also credits Dyson with crafting a serious and provocative assessment of the meaning of "the Black Presidency."

From our founding, the Du Bois Review: Social Science Research on Race has been dedicated to rising above the veil of race, to seeing and reporting on the dynamics of ethnoracial differentiation in its fullness. This issue assembles a number of pieces wherein the proverbial "other" assumes a new position in the analytical framework, or setting, or discussion and, in so doing, casts important and revealing light on the real dynamics of race. This approach should de-stabilize invidious processes of "othering" and serve to empower those too often relegated to "marked" categories. 